
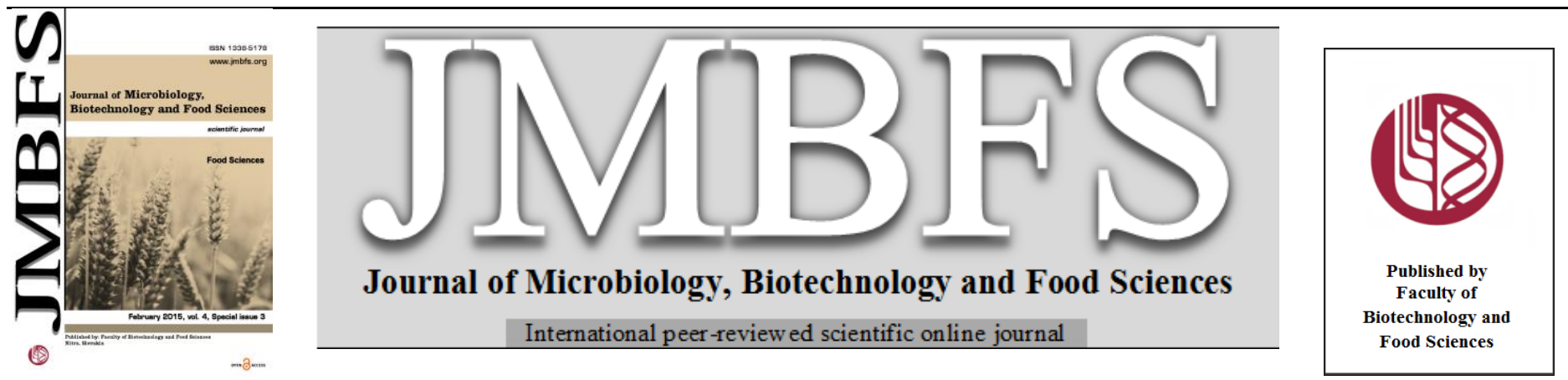

\title{
RELATIVE CHLOROPHYLL CONTENT CHANGES DURING UPTAKING OF SELENITE AND SELENATE BY MAIZE PLANTS GROWN IN NUTRIENT SOLUTION
}

\author{
Farzaneh Garousi $*^{1}$, Béla Kovács ${ }^{l}$, Szilvia Várallyay ${ }^{l}$, Éva Bódil ${ }^{l}$, Szilvia Veres ${ }^{2}$ \\ Address(es): Farzaneh Garousi \\ ${ }^{1}$ University of Debrecen, Faculty of Agricultural and Food Sciences and Environmental Management, Institute of Food Science, Böszörményi str. 138, H-4032 \\ Debrecen, Hungary, phone number: +36 52 508444/88506. \\ ${ }^{2}$ University of Debrecen, Faculty of Agricultural and Food Sciences and Environmental Management, Institute of Crop Sciences, Department of Agricultural Botany, \\ Crop Physiology and Biotechnology, Böszörményi str. 138, H-4032 Debrecen, Hungary.
}

*Corresponding author:farzaneh@agr.unideb.hu

doi: 10.15414/jmbfs.2015.4.special3.44-47

\section{ARTICLE INFO}

Received 20.11.2014

Revised 3. 12.2014

Accepted 4. 12. 2014

Published 2. 2. 2015

Regular article open 2 access

\begin{abstract}
Chlorophyll content (chl), one of the most important physiological parameters related to plant photosynthesis, is usually used to predict plant potential and portable, non-destructive chlorophyll meters could be a valuable and effective tool for estimating Relative Chlorophyll Content (RCC) in leaves. In this study, two species of soluble inorganic Selenium forms, selenite $\left(\mathrm{Se}^{\mathrm{IV}}\right)$ and selenate $\left(\mathrm{Se}^{\mathrm{VI}}\right)$ at different concentrations were investigated on maize plants that were growing in nutrient solutions during 2 weeks and changes of RCC within this time was monitored. It means chlorophyll content of three leaves of maize when everyone grew completely was measured according to Special Products Analysis Division (SPAD) value and the results revealed that high concentrations of $\mathrm{Se}^{\mathrm{IV}}$ (10, 30 and $\left.90 \mathrm{mg} \cdot \mathrm{kg}^{-1}\right)$ were toxic for maize even lower amounts $\left(1\right.$ and $\left.3 \mathrm{mg} \cdot \mathrm{kg}^{-1}\right)$ had effects of damage on it while this state wasn't adjusted for lower concentrations of $\mathrm{Se}^{\mathrm{VI}}\left(1\right.$ and $\left.3 \mathrm{mg}^{-\mathrm{kg}^{-1}}\right)$ and treated samples didn't have significant differences with controls although in higher amounts $\left(10\right.$ and $\left.30 \mathrm{mg} \cdot \mathrm{kg}^{-1}\right)$ toxic effects were seen in them, too.
\end{abstract}

Keywords: Relative chlorophyl content, sodium selenite, sodium selenite, maize

\section{INTRODUCTION}

Selenium ( $\mathrm{Se}$ ) is an essential micronutrient for the health of mammals and mainly enters food chains through plants. To provide recommended optimal Se values for target population, agronomic Se-biofortification (e.g., adding soluble selenite and selenate salts to mineral fertilizers) seems to be a good short-term strategy to accumulate higher levels of $\mathrm{Se}$ in plants. Despite substantial literature on Se uptake by plants and crops such as wheat, little consideration has been given to maize (Zea mays), a low "Se-indicator" plant but the world's most widely grown cereal. To date there have been few publications on Se uptake and assimilation in this plant Castrec-Rouelle et al. (2011) and parallel to that, investigation of its effects on maize leaves' chlorophyll content.

Chlorophyll is a frequent organic chemical component because it is naturally present in plants, giving their specific coloration Withnallas et al. (2003) as a photosynthetic pigment and an essential component of the plant photosystem. Leaf chlorophyll content affects photosynthetic ability and thus is one of the most important physiological traits affecting plants (Czyczylo-Mysza et al., 2013; Teng et al., 2004; Wang et al., 2008) so that content of photosynthetic pigments is highly correlated with the nutrition condition Gitelson $\boldsymbol{e t}$ al. (2003) and as an indicator for growth and survival of plants (Foyer et al., 1982; Peng and Gitelson, 2012).

The objective of our study was to expose maize plants to Se in both forms of sodium selenite and sodium selenate as well as investigation of their uptake effects on maize leaves' RCC.

\section{MATERIAL AND METHODS}

\section{Materials}

Sodium selenite and sodium selenate were obtained from SIGMA-ALDRICH LTD. (POOLE, UK) and Chlorophyll meter (MINOLTA SPAD-502) was supplied by KONICA-MINOLTA, JAPAN.

\section{General plant propagation}

Maize (Zea mays L. cv. Norma SC) as a monocotyledon plant was chosen for our research. Disinfected maize seeds were geotropically germinated between moist filter papers in $22^{\circ} \mathrm{C}$. Seedlings with $2.5-3.0 \mathrm{~cm}$ coleoptile were placed into aerated nutrient solution pots. Maize plants were grown up in a climate room under strictly regulated environmental conditions. Relative humidity was maintained between $65-75 \%$, light/dark cycle was $16 / 8 \mathrm{hrs}$. with a respective $25 / 20^{\circ} \mathrm{C}$ temperature periodicity, and light intensity was kept in constant 300 $\mu$ mol. $\mathrm{m}^{-2} \mathrm{~s}^{-1}$ during daytime.

\section{Plant growth in nutrient solution}

The nutrient solution that was used for plant growth had the following composition: $2.0 \mathrm{mM} \mathrm{Ca}\left(\mathrm{NO}_{3}\right)_{2}, 0.7 \mathrm{mM} \quad \mathrm{K}_{2} \mathrm{SO}_{4}, 0.5 \mathrm{mM} \mathrm{MgSO}_{4}, 0.1 \mathrm{mM}$ $\mathrm{KH}_{2} \mathrm{PO}_{4}, 0.1 \mathrm{mM} \mathrm{KCl}, 0.1 \mu \mathrm{M} \mathrm{H} \mathrm{BO}_{3}, 0.5 \mu \mathrm{M} \mathrm{MnSO}_{4}, 0.5 \mu \mathrm{M} \mathrm{ZnSO}_{4}$ and $0.2 \mu \mathrm{M} \mathrm{CuSO}_{4}$. Iron was supplied in the form of $10^{-4} \mathrm{M}$ Fe-EDTA, too (Cakmak and Marschner, 1990).

Selenium was supplemented to the nutrient solution as two species of selenite in form of $\mathrm{Na}_{2} \mathrm{SeO}_{3}$ and selenate in form of $\mathrm{Na}_{2} \mathrm{SeO}_{4}$ in five and four different concentrations respectively as follows: 0 (control), 1, 3, 10, 30 and 90 mg.kg$\mathrm{Se}^{\mathrm{IV}}$ and 0 (control), 1, 3, 10 and $30 \mathrm{mg} \cdot \mathrm{kg}^{-1} \mathrm{Se}^{\mathrm{VI}}$. Nutrient solution was changed every 3 days and evaporated water was replenished regularly. The experiment ended 2 weeks after planting when third leaf of control treatment grew completely and seedlings had approximately 40-30 cm long shoots and roots, respectively. Experiments were carried out in triplicates

\section{Chlorophyll measurements (SPAD)}

According to SPAD value five different parts' average of three leaves were measured by portable, non-destructive chlorophyll meters when every leaf of maize plants grew completely.

\section{Statistical analysis}

All data were statistically analyzed using SPSS 17.0 software, and the mean values of each treatment group were subjected to multiple comparisons analysis using the Two-Way ANOVA and a significance level of $\mathrm{p}<0.05$. 
The bars indicate the standard error of the mean. Significant differences in the mean value of each treatment group are indicated by different lowercase letters based on the Duncan test $(\mathrm{p}<0.05, \mathrm{n}=3)$.

\section{RESULTS AND DISCUSSION}

$\mathrm{Se}^{\mathrm{IV}}$ uptake effects on $\mathrm{RC}$

Fig. 1 displays chlorophyll contents (SPAD value) in maize leaves at different concentrations of $\mathrm{Se}^{\mathrm{IV}}$ for three times of three leaves RCC measurements but samples that had been treated by more than $3 \mathrm{mg} \cdot \mathrm{kg}^{-1}$ didn't grow so that 90 mg. $\mathrm{kg}^{-1}$ treatments got dried and RCC measurement was impossible for them. As is obvious in these figures, SPPAD value significantly increased for first leaf due to increasing application of $\mathrm{Se}^{\mathrm{IV}}$ but about second time there wasn't significant increasing and again for third time just first leaf had significant changes.
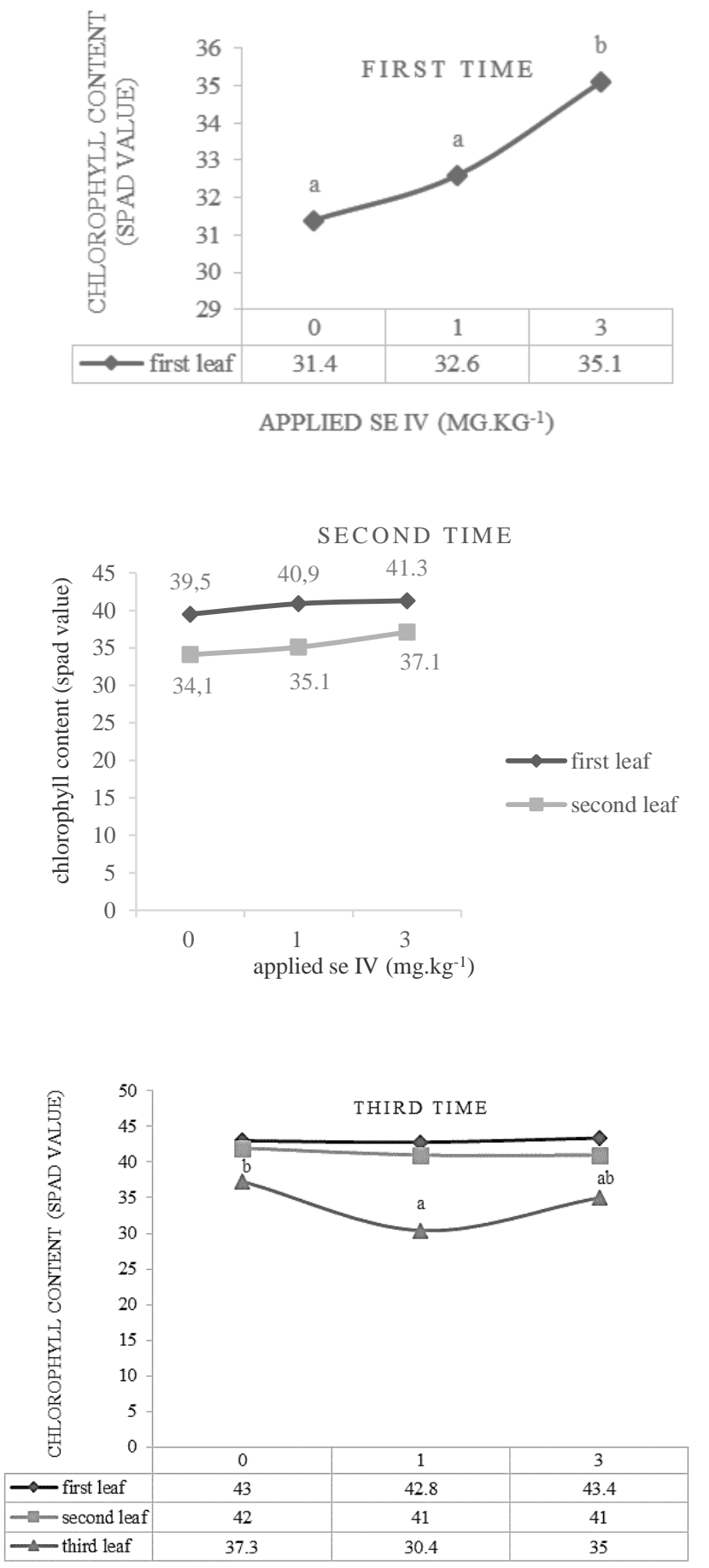

APPLIED SE IV (MG.KG-1)

Figure $1 \mathrm{Se}^{\mathrm{IV}}$ uptake effects on RCC. Significant differences in the mean value of each treatment group are indicated by different lowercase letter based on the Duncan-test ( $\mathrm{p}<0.05, \mathrm{n}=3)$. 


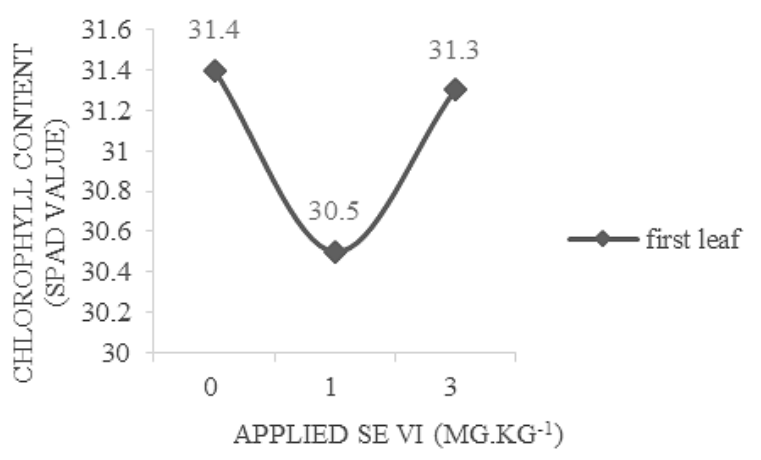

SECOND TIME

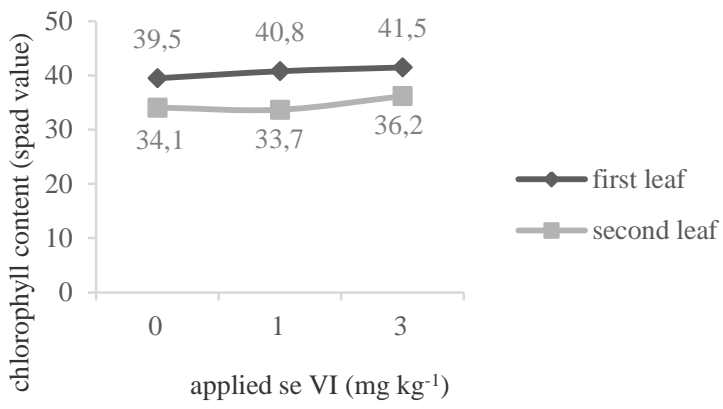

THIRD TIME

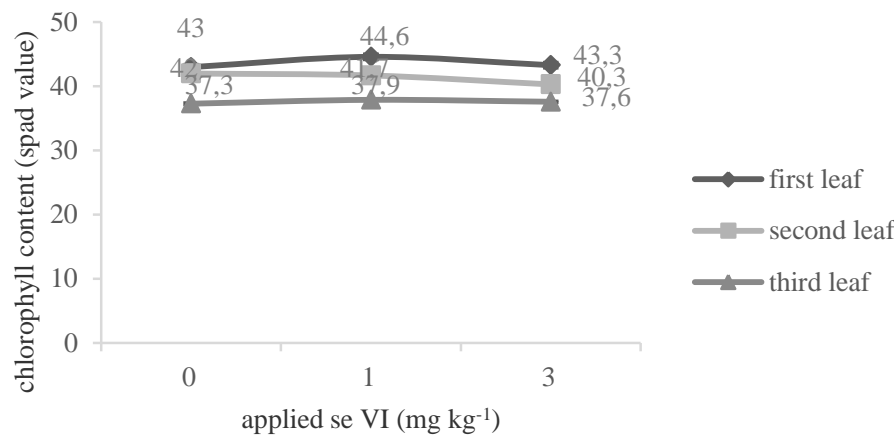

Figure $2 \mathrm{Se}^{\mathrm{VI}}$ uptake effects on RCC.

Changes of fresh and dry weight of maize shoots by increasing the application of $\mathrm{Se}^{\mathrm{IV}}$ and process of weight decrease has been showed (Tab 1).

Table 1 Different concentrations of $\mathrm{Se}^{\mathrm{IV}}$ uptake effects on fresh and dry weight of maize shoot.

\begin{tabular}{|c|c|c|}
\hline Applied Se $e^{I V}\left(m g g^{-I}\right)$ & Fresh weight (g) & Dry weight (g) \\
\hline $\mathbf{0}$ & $8.6379 \pm 0.8418^{c}$ & $0.6083 \pm 0.0742^{\mathrm{b}}$ \\
\hline 1 & $5.5065 \pm 0.9534^{\mathrm{b}}$ & $0.4543 \pm 0.0796^{\mathrm{a}}$ \\
\hline 3 & $3.6023 \pm 0.6422^{\mathrm{a}}$ & $0.3510 \pm 0.0451^{\mathrm{a}}$ \\
\hline
\end{tabular}

Significant differences in the mean value of each treatment group are indicated by different lowercase letter based on the Duncan-test ( $p<0.05 n=3 \pm$ s.e.)

\section{$\mathrm{Se}^{\mathrm{VI}}$ uptake effects on RCC}

Fig. 2 displays chlorophyll contents (SPAD value) in maize leaves at different concentrations of $\mathrm{Se}^{\mathrm{VI}}$ for three times of three leaves RCC measurements but samples that had been treated by more than $3 \mathrm{mg} \cdot \mathrm{kg}^{-1}$ didn't grow so that 30 mg. $\mathrm{kg}^{-1}$ treatments got dried and RCC measurement was impossible for them SPPAD value didn't change significantly for all of three leaves due to increasing application of $\mathrm{Se}^{\mathrm{VI}}$.

Tab 2 shows changes of fresh and dry weight of maize shoots by increasing the application of $\mathrm{Se}^{\mathrm{VI}}$.
Table 2 Different concentrations of $\mathrm{Se}^{\mathrm{VI}}$ uptake effects on fresh and dry weight of sunflower and maize shoot.

\begin{tabular}{ccc}
\hline Applied S $\boldsymbol{e}^{\boldsymbol{V I}}\left(\boldsymbol{m g ~ \boldsymbol { ~ g } ^ { - 1 } )}\right.$ & Fresh weight $(\mathrm{g})$ & Dry weight $(\boldsymbol{g})$ \\
\hline $\mathbf{0}$ & $8.6379 \pm 0.8418^{\mathrm{a}}$ & $0.6083 \pm 0.0742^{\mathrm{a}}$ \\
$\mathbf{1}$ & $8.1375 \pm 1.6916^{\mathrm{a}}$ & $0.6183 \pm 0.1443^{\mathrm{a}}$ \\
$\mathbf{3}$ & $8.0187 \pm 0.2765^{\mathrm{a}}$ & $0.6174 \pm 0.0223^{\mathrm{a}}$ \\
\hline Legend: The same lowercase letters after the mean values and standard deviations in both \\
culomns shows no significant defference between the treatments according to the Duncan- \\
test $(\mathrm{p}<0.05 \mathrm{n}=3 \pm$ s.e. $)$.
\end{tabular}

\section{CONCLUSION}

The data in this study indicate that portable chlorophyll meter is an effective tool for rapid and nondestructive estimation of relative chlorophyll content in maize leaves during the growing and treatment by two Se forms of selenite and selenate. As has been investigated in this paper, high doses of Se in both forms of $\mathrm{Se}^{\mathrm{IV}}$ and $\mathrm{Se}^{\mathrm{VI}}$ are toxic for maize plant. Moreover, in lower doses according to SPAD value and weight amount results, samples which had been treated by $\mathrm{Se}^{\mathrm{IV}}$ still had significant differences with control samples and effects of damage on maize growth whereas this state wasn't seen in $\mathrm{Se}^{\mathrm{VI}}$ treatments and there wasn't significant difference between treated and control samples in three times of RCC measurement. 


\section{REFERENCES}

CAKMAK, I., MARSCHNER, H. 1990. Decrease in nitrate uptake and increase in proton release in zinc deficient cotton, sunflower and buckwheat plants. Plant and Soil. 129, 261-268.

CASTREC-ROUELLE, M., LONGCHAMB, M., ANGELI, N. 2011. Uptake of selenate and/or selenite in hydroponically grown maize plants and interaction with some essential elements (calcium, magnesium, zinc, iron, manganese, and copper). Selenium (Global perspectives of impacts on humans, animals and the environment) Suzhou : China, 83-89.

CZYCZYŁO-MYSZA, I., TYRKA, M., MARCIŃSKA, I., SKRZYPEK, E., KARBARZ, M., DZIURKA, M., HURA, T., DZIURKA, K., QUARRIE, S.A 2013. Quantitative trait loci for leaf chlorophyll fluorescence parameters, chlorophyll and carotenoid contents in relation to biomass and yield in bread wheat and their chromosome deletion bin assignments. Molecular Breeding, 32(1), 189-210.

http://dx.doi.org/10.1007/s11032-013-9862-8

FOYER, C., LEEGOOD, R., WALKER, D. 1982. What limits photosynthesis? Nature, 298-326.

GITELSON, A.A., GRITZ †, Y., MERZLYAK, M.N. 2003. Relationships between leaf chlorophyll content and spectral reflectance and algorithms for nondestructive chlorophyll assessment in higher plant leaves. Journal of Plant Physiology, 160(3), 271-282.

http://dx.doi.org/10.1078/0176-1617-00887

PENG, Y., GITELSON, A.A. 2012. Remote estimation of gross primary productivity in soybean and maize based on total crop chlorophyll content. Remote Sensing of Environment, 117, 440-448. http://dx.doi.org/10.1016/j.rse.2011.10.021

TENG, S., QIAN, Q., ZENG, D., KUNIHIRO, Y., FUJIMOTO, K., HUANG, D. ZHU, L. 2004. QTL analysis of leaf photosynthetic rate and related physiological traits in rice (Oryza sativa L.). Euphytica, 135(1), 1-7.

http://dx.doi.org/10.1023/b:euph.0000009487.89270.e9

WANG, F., WANG, G., LI, X., HUANG, J., ZHENG, J. 2008. Heredity, physiology and mapping of a chlorophyll content gene of rice (Oryza sativa L.) Journal of Plant Physiology, 165(3), 324-330.

http://dx.doi.org/10.1016/j.jplph.2006.11.006

WITHNALL, C.B., SILVER, J., EDWARDS, H.G.M., de OLIVEIRA, L.F.C.

2003. Spectrochimica Acta A, 59, 2207-2212. 